\title{
Cultivation Mode of Students' Innovation and Entrepreneurship Ability in Applied Undergraduate Colleges
}

\author{
Xiangrui Meng \\ Applied Technology College \\ Dalian Ocean University \\ Dalian, Liaoning, 116300, China
}

\begin{abstract}
Innovation and entrepreneurship education in applied undergraduate colleges in China has developed rapidly in recent years with the emergence of innovative and entrepreneurship education demonstration schools such as Xiamen University and Suzhou University. Based on the immature educational concept of innovation and entrepreneurship, the imperfect innovation and entrepreneurship education system, the shortage of educational resources and the contradiction with the traditional teaching mode, the corresponding measures were put forward. From the new perspective of applied undergraduate colleges, this work, combined with the characteristics of regional economic culture, systematically studied and discussed the cultivation path of innovative and entrepreneurial talents in applied undergraduate colleges. The contribution of this work offers some references for further reform and improvement of talent cultivation paths in higher education institutions in China.
\end{abstract}

Keywords-Application-oriented; entrepreneurship; Ability cultivation

Innovation

and

\section{INTRODUCTION}

At present, due to the contrast between the employment difficulty of college students and the serious shortage of talents required by enterprises, the talent cultivation model in applied undergraduate colleges must take the innovative spirit and entrepreneurial skills as the basic objectives of talent cultivation. Guided by the educational principle of "generally cultivating and improving students' innovative consciousness and ability", applied undergraduate colleges are required to determine the "professional-based" and "professional and industrial deep integration" educational approaches in practice, strengthen the cooperative innovation ability of specialty and industry development, enhance innovation performance and improve the market demand for talents. For applied undergraduate colleges, to build innovative entrepreneurship talent cultivation system with professional characteristics, it is necessary to integrate professional courses, business simulation, practical exploration, competition incentives and innovative entrepreneurship base construction into a "five-in-one" cultivation model. In realizing the goal of innovation and entrepreneurship education, it should form a three-dimensional and comprehensive corresponding relationship that is complementary to each other, so as to enable students to realize "inspiring innovation and entrepreneurship consciousness, training innovation and entrepreneurship thinking, experiencing innovation and entrepreneurship process, enhancing innovation and entrepreneurship ability, transforming innovation and entrepreneurship" as far as possible in the process of participating in teaching practice activities. This is the basis for popularizing innovation and entrepreneurship education and establishing a brand-new "great entrepreneurship education concept".

\section{Problems Existing IN THE Cultivation OF}

\section{STUDENTS' INNOVATION AND ENTREPRENEURSHIP ABILITY IN} APPLIED UNDERGRADUATE COLLEGES

\section{A. The curriculum system is updated slowly}

The existing curriculum system in applied undergraduate colleges can not fully meet the needs of innovative entrepreneurial talents in the current social and economic development. Innovation awareness is not innate. A few people are born with innovator DNA, while most people's innovation attribute depends on cultivation. This requires business colleges to focus on the cultivation of innovative spirit, innovative consciousness and entrepreneurship when designing talent cultivation programs. Most of the school curricula are not updated according to the development of economy and society, which to some extent affects the quality of innovation and entrepreneurship education and the improvement of college students' innovation and entrepreneurship ability.

\section{B. Ideological understanding is not yet fully in place}

By discussing the talent cultivation mode of business colleges, the competitiveness in applied undergraduate colleges can be enhanced. However, many colleges do not realize the importance of innovative entrepreneurship education, and the understanding of innovative entrepreneurship education is only staying in meetings and documents. They believe that innovative entrepreneurship education reform is a small-scale practical activity participated by some students and a small number of teachers, so it has not really been implemented in the key links of education and teaching such as teaching concepts and training models, and has not been implemented in the teaching and practice of teachers and students [1]. In a narrow sense, it is a misunderstanding of the national policy to interpret innovation and entrepreneurship as an expedient measure to cope with the employment difficulties for college graduates under the current economic downward. This 
misunderstanding will inevitably affect the development of innovation and entrepreneurship education.

\section{Innovation and entrepreneurship education divorce from professional education}

The core of innovation and entrepreneurship is to improve college students' professional quality. Basic scientific research is the most fundamental direction of education. In some colleges, innovation and entrepreneurship education is separated from professional education, and the policies formulated are not specific, lacking pertinence and effectiveness. This kind of innovation and entrepreneurship education is empty and meaningless. Professional-based innovation and entrepreneurship education must focus on the long-term, encourage colleges to tap the resources of innovation and entrepreneurship in professional courses, and create special disciplines and research rooms. Guided by social needs, the structure of discipline and specialty and the type of personnel cultivation are optimized to provide innovative talents for the society.

\section{IMPROVEMENT MEASURES FOR CULTIVATING STUDENTS' INNOVATION AND ENTREPRENEURSHIP ABILITY IN APPLIED UNDERGRADUATE COLLEGES}

\section{A. Transform innovative thinking}

1) Establishing the concept of entrepreneurship education and cultivating entrepreneurship culture

American colleges have an open, free, tolerant and practical entrepreneurship culture. The entrepreneurship education concepts of college management and teachers are prominent. American college students are more motivated to receive entrepreneurship education and participate in entrepreneurship activities. They have a strong sense of entrepreneurship, clear motivation and scientific attitude towards entrepreneurship. Compared with American colleges, the entrepreneurship education concept of college management and teachers in China is weak. The entrepreneurship culture atmosphere is not strong enough, and the proportion of college students' entrepreneurship is not high. Therefore, it is necessary to draw lessons from the experience of the United States, make full use of the college portal, radio stations, school newspapers, school magazines, newspapers, etc., as well as campus BBS, QQ group, Facebook, Post bar, Weibo, etc., and give full play to the leadership and coordination of school management departments such as the school league committee, the school students' affairs office, the school office of academic studies, etc. It should also play the role of the school press corps, school entrepreneurship education institutions and entrepreneurial voluntary organizations as a fortress, It should also give full play to the role of school press corps, school entrepreneurship education institutions and voluntary entrepreneurship organizations as a battle fortress, increase the propaganda of entrepreneurship education, strengthen the concept of entrepreneurship education, cultivate an open, tolerant, free and practical entrepreneurship culture, enhance students' awareness of entrepreneurship, entrepreneurial attitude and risk awareness, and clarify their entrepreneurship initiatives and entrepreneurial goals. At the same time, college management should attach great importance to the cultivation of entrepreneurship talents, and regard entrepreneurship education as the focus of higher education quality engineering reform. Based on the teaching management, fund support, mentor allocation, reward and recognition, college students' entrepreneurship is encouraged and supported. It is necessary to actively guide the news media, vigorously publicize the policies and measures of the Party and the government to promote college students' entrepreneurship, publicize the advanced models of graduates' entrepreneurship, and strive to create a good public opinion atmosphere for college students' entrepreneurship.

2) Stimulating self-cultivation motivation and strengthening the consciousness of innovation and entrepreneurship ability

The folk saying "master leads the door, practice in the individual" shows the importance of students' self-determination. In the process of learning and practice, college students should pay attention to the cultivation of their own innovative and entrepreneurial ability and consciousness, and they should do the following:

Firstly, college students should establish an awareness of endless learning. Innovation and creation come from rich knowledge and irrepressible interest. "Innovative consciousness belongs to the category of attitude towards reality in personality structure. It is characterized by active thinking, non-conformity, creativity and criticism, the courage to stand out from the outside world, unique spirit and pursuit". In the process of learning and practice, college students should not be satisfied with the status quo and stand still. They should maintain their desire for new knowledge and fields and strong interest in learning. Reading and practice are the best ways to learn.

Secondly, college students should build up self-confidence and dare to question. Dante, the great poet, said, "it is my confidence that makes me float in the mire of life without being defiled". Mao Zedong once said, "confidence in two hundred years of life will be three thousand miles. Confident people are deep and arrogant". College students should be full of self-confidence and firm convictions, and don't look around and look forward to the future. In learning, it is necessary to believe in your own judgments and abilities, to dare to question teachers and authorities, to have your own opinions on everything, and to cultivate your own sense of innovation in the process of dealing with problems.

\section{B. Building an entrepreneurial platform}

1) Building a pluralistic system of entrepreneurship education institutions

The United States has established a diversified entrepreneurial education institution system combining official entrepreneurial service agencies, social intermediary service agencies, school entrepreneurial service organizations, entrepreneurial associations and clubs to provide entrepreneurial guidance, consulting, investment and financing services, and technical support for college students. Compared with American colleges, the construction of entrepreneurial education institutions in China's colleges is lagging behind [2]. Therefore, it is necessary to strengthen the construction of industrial education institutions, improve the administrative 
institutions, educational institutions, research institutions and service institutions for entrepreneurship education, and form a diversified entrepreneurial education institution system. All provincial education administrative departments and colleges should take entrepreneurship education as an important way to train entrepreneurial talents, and generally establish institutions such as local and college entrepreneurship education guidance centers. The departments of teaching affairs, student work and employment in colleges should work together to promote the construction of entrepreneurship guidance courses. Conditional colleges should set up entrepreneurship guidance teaching and research rooms to encourage and support college students to set up, participate in entrepreneurship associations and entrepreneurship clubs independently. In addition, qualified colleges can also learn from MIT's practice of establishing "Technology License Transfer Office" to provide the necessary support for college students' entrepreneurship in aspects of intellectual property protection, technology innovation and transfer, and financial support.

2) Constructing the "three spirals" platform for entrepreneurship

In the era of the knowledge economy, the "three spirals" have crossed the functional boundaries of colleges, industries and governments, and are committed to building a research-technology community to achieve the coordinated development of technology and research system. In the process of cultivating entrepreneurship talents, colleges, industries and governments should cooperate closely and complement each other to reassemble knowledge flow. For example, colleges capitalize knowledge and encourage the establishment of new companies originating from university academic research to play the role of industry. Industry trains employees in order to improve their working skills, and promotes knowledge sharing and transfer through the establishment of educational institutions within enterprises, which is similar to the functions of colleges. The government provides public research funds, like a venture capitalist, to promote the government's regular activities in innovation. American colleges pay attention to the construction of an entrepreneurial platform for college students. They closely combine laboratories, experimental bases, college science parks, off-campus enterprises and non-governmental organizations to promote close cooperation among colleges, enterprises, government and society in the process of cultivating entrepreneurial talents [3]. Therefore, we should learn from the experience of American colleges such as Stanford and MIT, make full use of the teaching and research bases both inside and outside the college, and strengthen the construction of college entrepreneurship science park and industry-college-research center. It is necessary to promote cooperation and exchanges between schools and governments, enterprises, grass-roots autonomous organizations and social organizations in the process of training entrepreneurship talents, build a "triple spirals" entrepreneurship platform, and promote the transformation of college's scientific and technological innovation ability and achievements.

\section{Expanding the carrier of practical education}

Social practice is an experiential teaching activity in which the school makes use of the students' spare time, such as holidays, in accordance with the goal of college education and training, to enable students to participate in social, political, economic and cultural life in a planned, purposeful and organized way. It is a useful supplement to classroom teaching and plays a vital role in training talents in schools. To enrich the practical activities for college students, efforts can be made in many ways. For example, social practice activities in winter and summer vacation every year can organize a wide range of activities out of the campus so that students of different grades and majors can walk out of the classroom and enter the society. Let the students make use of the long vacation to contact the society, to understand the social dynamics of the frontier, to do more social surveys, to contact with the actual life, to grasp the first-hand information, and lay a practical foundation for the future study and life [4].

In addition, the school can also unite enterprises and institutions to let students use the holidays to enter the enterprise. They can integrate into the enterprise by feeling the atmosphere of the enterprise, understanding the operation of the enterprise, participating in the management of the enterprise and offering advice for the development of the enterprise. On the one hand, they can test the theory they have learned, on the other hand, they can find their own shortcomings in learning. It can also improve the competitiveness of college students in employment [5]. Such a way to promote the better development of college students is a rare act.

In practical work, we should keep back the pulse of the times and deeply understand the connotation and laws of social practice. Only by combining social practice activities with international and domestic situations, integrating with the main theme of the times, focusing on school education policies and central work, objectively reflecting the inherent needs of young students to grow up, and creatively opening up new ways, can social practice activities be endowed with new vigor and give full play to its irreplaceable educational function. The content innovation and form innovation of social practice will not become the water without the source and the wood without foundation. Only in this way can the students we cultivate remain invincible in the fierce competition. At the same time, it is necessary to strengthen the construction of the social practice base and guide the long-term and localized development of social practice activities. While consolidating the original base, schools should actively encourage colleges to open up new social practice bases according to the advantages of disciplines [6]. After establishing a good base, the construction of the practice base is not only directly related to whether social practice activities can be guided to long-term and positioned development, but also creates indispensable conditions for college students to improve their innovative ability and cultivate innovative talents.

\section{CONCLUSION}

To sum up, as an important carrier to cultivate future successors in China, colleges must keep pace with the times and innovate bravely, vigorously promote the reform of higher education, reform the personnel training mode, and focus on cultivating students' innovative spirit and entrepreneurial ability. Through improving the policies related to innovation and entrepreneurship, students' innovation and 
entrepreneurship are provided with institutional guarantee and financial support. By strengthening the in-depth cooperation with enterprises and jointly building an innovation and entrepreneurship practice platform with enterprises, students' innovation and entrepreneurship are provided with more powerful support. It is necessary to create a good campus culture atmosphere of innovation and entrepreneurship, so that students fully realize that innovation and entrepreneurship is an effective way to realize their own value, and make greater contributions to the economic development and social harmony and stability in China with limited time and space.

\section{ACKNOWLEDGMENT}

This work is the phased results of the research on the Dalian vocational and technical education research institute in 2019, "Study on the Cultivation of Students' Innovation and Entrepreneurship in Vocational Colleges - Taking Applied Undergraduate Colleges as an Example" (Project No.: DZKY2019B07).

\section{REFERENCES}

[1] Ma Yongbin, Bai Zhe. Research and Exploration on the Practice Model of Innovation and Entrepreneurship Education in Colleges [J]. Education Research in Tsinghua University, 2018 (11): 99-103.

[2] Xu Mei. Constructing a System of Internal and External Linkages in Innovation and Entrepreneurship Education [J]. Employment of Chinese College students, 2016 (2): 4.

[3] Tang Meihua. Promoting the Employment Ability of College Students Based on Professional Ability Cultivation [J]. Journal of Science and Technology, 2017 (5): 224-225.

[4] Yuan Xingguo. The Cultivation Mode of Innovative and Entrepreneurial Talents in Applied Undergraduate Colleges [J]. Jiangsu Social Sciences, 2017 (12): 20-23.

[5] Wang Fenglian, Xie Rongjian, Wang Banglun, et al. The Cultivation Mode of Innovative and Entrepreneurial in Business Administration Major under the Background of "Internet Plus" [J]. Journal of Shaoxing University (Education Edition), 2017 (10): 32-37.

[6] $\mathrm{Xu}$ Guoquan. Influencing Factors and Countermeasures of Entrepreneurship Education in Colleges [J]. Journal of Ideological \& Theoretical Education, 2016 (6): 110. 